\title{
Komunikacja niewerbalna a tlumaczenie symultaniczne: aspekt empiryczny
}

\section{Non-verbal communication and simultaneous interpreting: the empirical aspect}

\begin{abstract}
Bearing in mind the prime principle of audiovisual integration in human communication (Seeber 2012, 2017), the author discusses the empirical aspects of the correlation between nonverbal communication and simultaneous interpreting. Having established that kinesics and prosody indeed can have a positive impact on understanding one's message, he conducts an experiment in which he compares the quality of the interpretations performed by MA students of English and Russian philology divided into audio and audio-visual groups in the case of English-Polish and Russian-Polish simultaneous interpreting. He focuses specifically on two categories of gestures - illustrators and emblems. Ultimately, he discovers a tangible relation between having the ability to see the speaker and the accuracy of interpreting the speaker's speech. However, the limitations of the experiment do not allow for making universal conclusions on the basis of its results, as it should become operationalised and replicated.
\end{abstract}

Keywords: nonverbal communication, simultaneous interpreting, audiovisual integration, experiment, gestures

Konrad Rachut, Uniwersytet im. Adama Mickiewicza w Poznaniu, Poznań - Polska, konrad. rachut@gmail.com, ORCID ID: https://orcid.org/0000-0002-3019-0592

Niniejszy artykuł stanowi kontynuację mojego wcześniejszego artykułu (Rachut), w którym poruszyłem aspekty teoretyczne związane z problemem korelacji pomiędzy komunikacją niewerbalną a tłumaczeniem symultanicznym. Podstawowe założenie, które eksplorowałem w jego ramach, brzmiało następująco:

zależność pomiędzy systemem znaków werbalnych i niewerbalnych wiąże się ze zjawiskiem integracji audiowizualnej w komunikacji międzyludzkiej, którego uzasadnieniem jest tendencja ludzkiego mózgu do łączenia wszelkich dostępnych płaszczyzn przekazu informacji w jedną całość. Badania neurolingwistów sugerują, iż sygnały niewerbalne wspierają i ułatwiają odbiór mowy (Rachut 66).

Bazą teoretyczną uzasadniającą konieczność uwzględniania płaszczyzny niewerbalnej w procesie tłumaczenia symultanicznego stał się model użycia zasobów 
kognitywnych opracowany przez Kiliana Seebera (Seeber 2017: 468; Rachut 73). Jest to konsekwencją tego, że

[p]rzekładoznawca opracował model przetwarzania audiowizualnego, w ramach którego zaprezentował zakres wykorzystania zasobów kognitywnych thumacza symultanicznego [...]. [Seeber] wyróżnił cztery równoważne płaszczyzny komunikacji bezpośredniej: słuchowo-przestrzenną (auditory-spatial), słuchowo-werbalną (auditory-verbal), wizualno-werbalną (visual-verbal) i wizualno-przestrzenną (visual-spatial) (Rachut 72; Seeber 2017).

Obranie takiej perspektywy pozwala uznać za zasadne przekonanie, zgodnie z którym płaszczyzna niewerbalna może odgrywać istotną rolę dla tłumacza i tworzonego przez niego przekładu ustnego. $Z$ tego względu celem niniejszego artykułu jest weryfikacja empiryczna, czy znaki niewerbalne, a w przypadku przeprowadzonego eksperymentu gesty wykonywane przez prelegentów i thumaczy ustnych w procesie thumaczenia symultanicznego, mają istotny wpływ na psychikę tłumacza i jakość przekładu symultanicznego jako produktu. W trakcie eksperymentu wykorzystałem mieszaną metodologię badawczą, która pozwoliła uwzględnić zarówno płaszczyznę werbalną przekładu symultanicznego, jak również jego przestrzeń niewerbalną.

Dotychczas przekładoznawcy podejmowali próby przebadania thumaczenia symultanicznego $\mathrm{z}$ uwzględnieniem roli odgrywanej w nim przez znaki niewerbalne, lecz stosowana przez nich metodologia i stawiane cele nie były spójne. Najważniejsze eksperymenty związane z tym zagadnieniem to: kwestionariusze Hildegund Bühler (Bühler), eksperyment Sylvi Rennert (Rennert) dotyczący wpływu na rozumienie komunikatu dostępu/braku dostępu do danych wizualnych, eksperyment Eleny Galvão (Galvão, źródło elektroniczne) dotyczący naśladowania gestów prelegenta przez thumaczy symultanicznych i eksperyment Seebera (Seeber 2012), w którym badacz przeanalizował ruchy gałek ocznych thumaczy symultanicznych świadczące o poszukiwaniu danych wizualnych. Założenia teoretyczne i praktyczne rezultaty tych badań poddałem weryfikacji w ramach eksperymentu, którego opis, hipotezy i wyniki zawarłem w dalszej części artykułu.

Wobec dwufazowości komunikacji w thumaczeniu symultanicznym, czyli kontaktu pomiędzy przedstawicielami odmiennych kultur i języków pośredniczonego przez tłumacza ustnego, jak również konsekwencji płynących z takiej sytuacji (odmiennych konwencji zachowania werbalnego i niewerbalnego, które w konfrontacji mogą prowadzić do nieporozumień, a nawet konfliktów) warto zastanowić się nad właściwościami komunikacji niewerbalnej i typologią gestów. Co ważne, zainteresowanie naukowców problematyką komunikacji niewerbalnej tak naprawdę doprowadziło do opracowania „gramatyki języka ciała”. Kluczowym postulatem $w$ ramach takich rozważań jest to, że składa się ona z jednostek znaczenia, które w ogólnym rozrachunku stanowią reprezentację intencji nadaw- 
cy. Dlatego też posługiwanie się terminem składnia języka ciała jest całkowicie uzasadnione. W tym ujęciu pojedyncze sygnały niewerbalne muszą być interpretowane jako większa całość, ponieważ wspólnie składają się na pasmo przekazu informacji.

Pierwszą właściwością komunikacji niewerbalnej jest ciąglość, która sprowadza się do czysto fizycznego aspektu komunikacji międzyludzkiej. Gdy uczestnicy rozmowy znajdują się w tym samym miejscu, są bezustannie obserwowani przez swoich interlokutorów (Verderber, Verderber, Sellnow 43). Daje to nieprzerwaną możliwość odczytywania stanu emocjonalnego poszczególnych osób i ich stosunku do danej sytuacji. Na przykład spoglądanie w dół lub na bok w trakcie ważnego spotkania biznesowego może świadczyć o braku zainteresowania tematem. W tego typu przypadkach osoba komunikuje się z pozostałymi, mimo że nie przekazuje eksplicytnej wiadomości werbalnej.

Drugą właściwością jest wielokanałowość, co oznacza, że znaki niewerbalne przekazują intencje mówiącego na wielu płaszczyznach (Verderber, Verderber, Sellnow 44). Interpretacja ludzkiego zachowania jest oparta na współdziałaniu postawy, gestów, ruchów ciała, mimiki, spojrzenia, wyglądu, melodii głosu (Verderber, Verderber, Sellnow 44). W ten sposób liczba niewerbalnych źródeł informacji, które odbiorcy komunikatu mogą wziąć pod uwagę, zdecydowanie przewyższa liczbę kanałów przekazu werbalnego, czyli dwa: wizualny (tekst) i audialny (mowa) (Fujishin 38).

Trzecią cechą komunikacji niewerbalnej jest intencjonalność związana $\mathrm{z}$ faktem, że nadawanie komunikatów za pośrednictwem znaków niewerbalnych jest u ludzi wrodzone. W konsekwencji są one zdecydowanie trudniejsze do skontrolowania niż zachowania werbalne. Wynika to prawdopodobnie z tego, że zasoby kognitywne dostępne ludziom w procesie komunikacji są zużywane przez trzy kluczowe procesy, czyli w kolejności chronologicznej, przedjęzykowe planowanie, formułowanie oraz artykulacja lub zapisanie (Grabowski 169). Z jednej strony nie oznacza to, że kontrolowanie sygnałów niewerbalnych jest niemożliwe - wymaga ono zdolności aktorskich, szczególnie w sytuacji, gdy nadawcy zależy na tym, by wyglądały one naturalnie i przekonująco. Z drugiej strony przesadne skupienie się na aspekcie niewerbalnym komunikacji może doprowadzić do wystąpienia błędów w trakcie wypowiadania słów.

Czwartą właściwością sygnałów niewerbalnych jest niejednoznaczność związana z subiektywnością interpretacji ich znaczenia (Verderber, Verderber, Sellnow 44). W istocie każdy komunikat może być niejednoznaczny, gdyż ludzie dekodują jego potencjał semantyczny, opierając się na własnym spojrzeniu na świat, doświadczeniach życiowych i procesach poznawczych. Wiąże się to z konotacjami przyjmującymi różne postaci w zależności od człowieka i przekładającymi się na odmiennie odczytywany sens komunikatu, co opiera się na języku, 
kulturze, wiedzy i psychice jednostki (Sternberg 375). Zasada ta ma zastosowanie również w przypadku komunikatów niewerbalnych, przez co istnieje wiele potencjalnych możliwości ich zdekodowania. Jeśli kontekst i kotekst rozmowy są niejasne, to intencja przypisana komunikatowi przez nadawcę może zostać odmiennie zrozumiana przez każdego odbiorcę.

Ostatnią właściwością znaków niewerbalnych jest ich prymarność w odzwierciedlaniu ludzkich emocji (Verderber, Verderber, Sellnow 45). Ma to związek z faktem, że język werbalny został wytworzony sztucznie, a historycznie poprzedza go komunikacja oparta właśnie na niewerbalności. Jest ona więc pozostałością reakcji instynktownych typowych dla świata zwierząt. Inaczej mówiąc, są to zautomatyzowane szablony zachowania stanowiące bazę funkcjonowania człowieka.

Mając na względzie charakterystykę komunikacji niewerbalnej w ogóle, przejdę do wyodrębnienia poszczególnych kategorii sygnałów niewerbalnych. Ponieważ w eksperymencie skupiono się wyłącznie na wpływie gestów na jakość przekładu symultanicznego, nie będę odwoływał się do prozodii, kontaktu wzrokowego, mimiki, postawy i wykorzystania przestrzeni.

Powołując się na typologię gestów autorstwa Paula Ekmana i Wallace'a Frisena (Ekman, Frisen), należy wyodrębnić pierwszą kategorię gestów, czyli emblematy. Ekman uznaje te gesty za właściwy język ciała ze względu na to, że mają one precyzyjne znaczenie, jednakowo odczytywane przez przedstawicieli tej samej kultury (Ekman 39). Typowym przykładem emblematów jest kciuk uniesiony do góry, znak zwycięstwa i gest Kozakiewicza - ich potencjał semantyczny jest na tyle rozbudowany, że mogą one zastąpić dłuższe związki wyrazowe (Verderber, Verderber, Sellnow 45). Należy jednak zaznaczyć, że fizycznie identyczny emblemat może być rozumiany inaczej w zależności od kultury, w której jest używany.

Na kategorię emblematów składają się dwie podkategorie, czyli emblematy ikoniczne i zakodowane arbitralnie (Ekman 40). Gesty należące do pierwszej podkategorii bezpośrednio wyrażają swoje znaczenie, natomiast gesty z drugiej podkategorii nie mają formalnego związku z niesionym znaczeniem, a ich interpretacja jest rezultatem umowy społecznej. Przykładowo, dotknięcie ust czubkiem palca jednoznacznie pokazuje prośbę o zamilknięcie, więc należy do podkategorii emblematów ikonicznych. Z kolei uniesiony do góry kciuk oznacza aprobatę, która nie wynika $\mathrm{z}$ formalnej postaci znaku, natomiast ma szerokie znaczenie kulturowe, czyli jest emblematem zakodowanym arbitralnie.

Drugą kategorią gestów są ilustratory używane w celu dopełnienia komunikatu przekazywanego za pomocą słów poprzez zobrazowanie istotnej dla mówiącego części wypowiedzi. Ten rodzaj gestów pełni zatem funkcję tła komunikacji (Osika 160). Zrozumiałe jest, że częstotliwość używania ilustratorów zależy od 
indywidualnych preferencji i przyzwyczajeń konkretnej osoby. Właśnie z tego powodu niektórych określa się jako osoby „mówiące rękoma” (Verderber, Verderber, Sellnow 45). Ta częstotliwość jest powiązana z poziomem zaangażowania emocjonalnego osoby mówiącej. Wyróżnia się następujące podkategorie ilustratorów: batuty, ruchy deiktyczne, ruchy rytmiczne i piktografy. Jako że ilustratory czynią proces komunikacji bardziej dynamicznym i wielowymiarowym, to pozwalają na przekonanie rozmówców do swojej racji. Na dodatek dzięki nim mówiący sprawia wrażenie osoby towarzyskiej i przyjaźnie nastawionej. Przykładowo, ilustratory to wskazywanie, wyliczanie i wzruszanie ramionami. Bez wątpienia są one komplementarne wobec znaczenia zawartego w przekazie słownym.

Trzecią kategorią gestów są regulatory, czyli sygnały niewerbalne służące kontrolowaniu naprzemiennej natury komunikacji (tury słuchania i mówienia) pomiędzy dwoma rozmówcami lub ich większą liczbą (Ekman 44). Innymi słowy, dzięki użyciu tych gestów współrozmówcy ukazują swoje role odgrywane na każdym z etapów komunikacji - na tej podstawie Ekman (Ekman 44) wyodrębnił cztery podkategorie regulatorów. Po pierwsze są to sygnaly zgody odbiorcy, czyli formy okazania pozytywnych odczuć ze strony słuchaczy, takie jak kiwanie głową lub wyraz aprobaty na twarzy. Po drugie są to wezwania do odpowiedzi, czyli sygnały niewerbalne, za pomocą których słuchacz komunikuje mówiącemu potrzebę wyjaśnienia czegoś - np. przez uniesienie brwi. Po trzecie są to podtrzymywacze wypowiedzi, a więc gesty wyrażające chęć mówcy do kontynuowania wypowiedzi, mimo że słuchacz chce mu przerwać - np. jest to dłoń skierowana spodem w stronę słuchacza. Po czwarte do regulatorów należą poszukiwacze zmiany, przy użyciu których słuchacze wyrażają swoją chęć zabrania głosu, takie jak wychylenie ciała do przodu lub podniesienie ręki.

Ostatnią kategorią gestów są manipulatory, które polegają na poruszaniu jedną częścią ciała przy użyciu innej, czyli np. jest to poprawianie okularów, bawienie się włosami lub kręcenie młynka kciukami (Ekman 43). Mogą one wyrażać odczucie dyskomfortu lub być zwyczajem konkretnej osoby. Są często nazywane adaptatorami, gdyż ich używanie obniża poziom stresu w interakcjach społecznych, tym samym pozwala osobie dostosować się do bieżącej sytuacji (Osika 161).

Podwaliny pod badania nad znaczeniem niewerbalności w tłumaczeniu symultanicznym stworzyła Bühler (Bühler). Przeprowadziła ona ankietę skupiającą się na aspekcie psychologicznym pracy doświadczonych tłumaczy symultanicznych. Ogólnym wnioskiem płynącym z udzielonych odpowiedzi było to, że dla tłumaczy niezbędna była możliwość obserwowania interakcji zachodzących pomiędzy prelegentami, widownią i pozostałymi thumaczami. Jeśli chodzi o zdanie ankietowanych odnośnie do funkcji pełnionej przez komunikację niewerbalną prelegentów, to twierdzili oni zgodnie, iż jej percepcja umożliwiała im precyzyj- 
niejsze tłumaczenie wypowiedzi, co szczególnie dotyczyło przypadków niezrozumienia słów lub problemów technicznych. Co się tyczy widowni, czyli również potencjalnych prelegentów, ich zachowania niewerbalne (zgłaszanie się, wstawanie z miejsca, podchodzenie do podium) pozwalały tłumaczom przygotować się na zmianę osoby mówiącej lub języka, dzięki czemu prawdopodobieństwo wytrącenia ich z rytmu diametralnie spadało. $Z$ kolei obserwowanie zachowania odbiorców dawało możliwość dostosowania przekładu do ich wymagań - reakcje negatywne sygnalizowały niezrozumienie i pozwalały na przeformułowanie przekładu. W kwestii utrzymywania kontaktu wzrokowego z pozostałymi thumaczami ankietowani zgodnie uznali, iż był to dla nich sposób na zasygnalizowanie potrzeby zasięgnięcia konsultacji merytorycznej lub wyrażenia chęci udzielenia jej. Podsumowując, z opinii tłumaczy przebadanych przez Bühler wynika, iż ci „,nie chcą pracować w próżni” i ze względu na to cenią sobie możliwość zapoznania się $\mathrm{z}$ atmosferą thumaczonej sytuacji komunikacyjnej.

Pierwsze próby eksperymentalnego zbadania problemu zostały podjęte przez Maurizia Balzaniego (Balzani), Lindę Anderson (Anderson) i Alexandrę Jesse $i$ in. (Jesse et al.). Celem wszystkich trzech doświadczeń było zweryfikowanie wpływu obecności lub braku dostępu do płaszczyzny wizualnej komunikacji tłumaczonej symultanicznie, jednak jednoczesne uwzględnienie wielu aspektów przestrzeni niewerbalnej (mimika, gesty, postawa ciała) nie pozwoliło na jednoznaczną interpretację wyników. Ogólnie rzecz biorąc, rezultaty tych eksperymentów pozwalają stwierdzić, że w przypadku umożliwienia dostępu tylko do strony werbalnej komunikacji tłumacze symultaniczni mają skłonność do popełniania większej liczby błędów niż w przypadku dostępu do pasma przekazu werbalnego i niewerbalnego. Eksperymenty te mają zatem potencjał do wskazania kierunku dalszych badań - konieczności skupienia się na relacji pomiędzy konkretną kategorią znaków niewerbalnych a jakością przekładu symultanicznego.

Jeśli chodzi o nowsze badania, to Rennert w swoim eksperymencie (Rennert) zajęła się problemem wpływu obecności lub nieobecności prelegenta w polu widzenia tłumacza na jakość przekładu symultanicznego. Uczestnicy badania zostali podzieleni na dwie grupy: członkowie pierwszej mieli dostęp zarówno wizualny, jak i słuchowy do prelegenta, członkowie drugiej mieli zaś dostęp tylko do pasma dźwiękowego, ponieważ zostali umieszczeni w ,ślepych kabinach” (ang. blind booths). Mimo że badaczka nie zauważyła wyraźnej korelacji pomiędzy obiema zmiennymi, w trakcie eksperymentu zaobserwowała przypadki, w których płaszczyzna niewerbalna stała się pomocna dla tłumaczących. Wynika to z kwestionariuszy wypełnionych przez uczestników eksperymentu po jego ukończeniu. Osoby tłumaczące w ,ślepych kabinach" zauważyły, że tłumaczenie bez kontaktu wzrokowego z prelegentem było trudniejsze, wymagało większej koncentracji i prowadziło do szybszego zmęczenia. Było to szczególnie widoczne w sytua- 
cjach, w których tłumaczący zdawali sobie sprawę, iż mówca przekazuje jakieś informacje za pomocą gestów dla nich niewidocznych. Nie ulega wątpliwości, że w tym kontekście obecność dodatkowego pasma wizualnego przekazu informacji mogła pozwolić tłumaczącym na obniżenie poziomu obciążenia kognitywnego. Należy zatem interpretować tłumaczenie ustne bez dostępu do pasma wizualnego thumaczonej wypowiedzi jako znacznie utrudnione.

Z kolei Galvão w swoim badaniu skupiła się na aspekcie niewerbalnym tłumaczenia symultanicznego $z$ pominięciem warstwy słownej, a więc gestykulacji połączonej z prozodią prelegenta i stopnia, w jakim thumacze ustni ją odzwierciedlają (Galvão). Liczba uczestników eksperymentu (dwoje) i przykładów podanych w publikacji (cztery) jest niewielka, niemniej jednak sama idea jest warta przybliżenia. Badaczka wysnuwa wniosek, iż uczestnicy badania rzeczywiście powtarzali zachowania niewerbalne prelegenta. Dla przykładu:

[...] the speaker's emphasis on well before is rendered by the interpreter through prosody (ascending pitch and higher intensity) as well as gesture (ample stroke). Both speaker and interpreter seem to reveal the same perception or comprehension of time through their gestures: they locate the past behind and the present right in front of them and draw a line with a forwards movement to indicate time progression ${ }^{1}$ (Galvão 15).

Te i inne sytuacje, w których doszło do odzwierciedlenia gestykulacji i prozodii prelegenta, pozwalają stwierdzić, że tłumacze w sposób naturalny wykorzystują komunikację niewerbalną w kabinach. Dzieje się tak, mimo że zdają sobie sprawę, że nie są widziani przez odbiorców tłumaczenia. Najwyraźniej jest to dla nich sposób na ułatwienie sobie procesu dobierania słów w trakcie tłumaczenia.

Seeber (Seeber 2012) w swoim doświadczeniu również skupił się na aspekcie niewerbalnym tłumaczenia symultanicznego - za cel obrał ustalenie, czy thumacze korzystają z pasma wizualnego przekazu informacji w procesie thumaczenia małych i dużych liczb. Wykorzystał do tego tzw. okulografy (eye tracker, eye tracking glasses) w konfrontacji z dwoma rodzajami przekazu: wizualno-przestrzennego (języka ciała) i wizualno-słownego (slajdów) (Seeber 2012: 344). Ruchy gałek ocznych uczestników dały podstawę do wysnucia wniosku, że sygnały niewerbalne traktowane są przez tłumaczy jako dodatkowe źródło informacji. W szczególności dotyczyło to slajdów, ponieważ w przypadku, gdy wyświetlano na nich liczby wypowiadane przez prelegenta, tłumacze patrzyli

${ }^{1}$, „[...] podkreślenie przez prelegenta frazy znacznie wcześniej jest odzwierciedlone przez tłumacza za pomocą prozodii (intonacja rosnąca i donośniejszy głos) i gestu (machnięcie ręką). Zarówno prelegent, jak i tłumacz wyrażają analogiczną percepcję albo rozumienie czasu za pośrednictwem swoich gestów: umieszczają przeszłość za sobą, a przyszłość bezpośrednio przed sobą, dodatkowo rysują w powietrzu linię skierowaną od siebie dla zwizualizowania upływu czasu" [przeł. K.R.]. 
na nie dwa razy dłużej w porównaniu z sytuacją, kiedy liczby nie były na nich wyświetlane. Co szczególnie interesujące, twarz prelegenta była obserwowana przez thumaczy zdecydowanie najdłużej (ok. 25 sekund w porównaniu do 10 sekund w przypadku slajdów i 5 sekund w przypadku gestów), chociaż zrozumiałe jest, że twarz nie jest w stanie zwizualizować liczb, w przeciwieństwie do slajdów i gestów (Seeber 2012: 345). Można wnioskować, że dążenie do wydobycia informacji ze znaków niewerbalnych jest, z jednej strony, świadome, lecz, z drugiej strony, instynktowne.

Przechodząc do opisu eksperymentu, chcę podkreślić, że punktem wyjścia było założenie, że komunikat prelegenta dociera do tłumaczy symultanicznych równolegle za pośrednictwem kanału audialnego i wizualnego. Mając na uwadze stwierdzone naukowo zjawisko integracji audiowizualnej w komunikacji (w tym w thumaczeniu symultanicznym), miałem na celu wykazanie, czy dostęp zarówno do audialnego, jak i wizualnego pasma przekazu informacji ma pozytywny wpływ na jakość przekładu symultanicznego. Przekłada się na to procentowy udział każdej z trzech płaszczyzn składających się na komunikat - eksperyment koncentruje się na kinezyce (języku ciała), która stanowi aż 60\% komunikatu. Jeśli chodzi o metodologię badania, to zastosowana procedura oparta jest na trzech spośród opisanych eksperymentów (Rennert; Galvão; Seeber 2012), natomiast metodologia oceny jakości przekładu symultanicznego została zainspirowana metodą opracowaną przez Magdalenę Bartłomiejczyk (Bartłomiejczyk). Eksperyment stanowi próbę wypracowania metodologii badawczej pozwalającej w wymierny sposób ocenić relację pomiędzy komunikacją niewerbalną a jakością przekładu symultanicznego. Wyniki badania i wnioski wyciągnięte na tej podstawie mogą przyczynić się do tego, iż praca thumaczy symultanicznych stanie się łatwiejsza, zostaną opracowane nowe strategie nauczania tłumaczenia symultanicznego, jak również zostanie zgłębiony aspekt teoretyczny poruszanego zagadnienia.

Eksperyment miał na celu zweryfikowanie następujących hipotez sformułowanych na podstawie wspomnianych wyżej doświadczeń:

1. Tłumacze, którzy widzą i słyszą prelegenta, tłumaczą lepiej od tych tłumaczy, którzy go tylko słyszą.

2. Tłumacze, którzy jedynie słyszą prelegenta, czują się bardziej zestresowani, zdezorientowani i odizolowani od tłumaczonej sytuacji komunikacyjnej w porównaniu z tymi tłumaczami, którzy widzą i słyszą prelegenta.

3. Tłumacze, którzy widzą i słyszą prelegenta, odzwierciedlają jego gesty, a tłumacze, którzy tylko słyszą prelegenta, gestykulują na swój indywidualny sposób.

Powyższe hipotezy zostały zweryfikowane na podstawie punktacji, którą uzyskały przekłady symultaniczne z języka angielskiego i rosyjskiego na polski wykonane przez członków dwóch grup eksperymentalnych: w jednej tłumacze 
zarówno słyszeli, jak i widzieli prelegentki (są to grupy audio-wideo), a w drugiej jedynie je słyszeli (są to grupy audio). Istotne jest to, że wystąpienia prelegentek zostały odtworzone z nagrania, a nie zaprezentowane na żywo. Wynikało to nie tylko z ograniczeń finansowych i technicznych eksperymentu, lecz również z faktu, że ważne było dla mnie to, aby wszyscy uczestnicy eksperymentu mieli do czynienia z identyczną postacią komunikatu źródłowego.

W eksperymencie wzięło udział siedmioro studentów II roku studiów magisterskich filologii angielskiej i pięcioro studentów I roku studiów magisterskich filologii rosyjskiej. Wszyscy studenci uczęszczali na specjalizację przekładoznawczą, w związku z czym w programie studiów mieli przewidziane zajęcia $\mathrm{z}$ thumaczenia ustnego, w tym symultanicznego. Należy zaznaczyć, iż grupa studentów filologii rosyjskiej zakończyła cykl zajęć z tłumaczenia symultanicznego 6 miesięcy przed eksperymentem. Dodatkowo grupa studentów filologii rosyjskiej była na I roku studiów magisterskich, zatem jej członkowie mogli mieć mniej doświadczenia i pewności w tłumaczeniu symultanicznym niż członkowie grupy studentów filologii angielskiej. Kluczowy jest fakt, iż tak mała liczba uczestników eksperymentu nie pozwoliła na poczynienie daleko idących uogólnień wyników, a wręcz odwrotnie - wnioski wyciągnięte z tych wyników należy interpretować jako tendencje, które muszą być zweryfikowane w ramach kolejnych badań.

Eksperyment został przeprowadzony w sali przystosowanej do zajęć z thumaczenia symultanicznego, wyposażonej w profesjonalne kabiny i telewizory umieszczone pod sufitem na środku sali. W każdej z kabin przed każdym uczestnikiem eksperymentu zostały ustawione aparaty cyfrowe, które filmowały ich od momentu wejścia do kabiny do momentu zakończenia thumaczenia. Nagrania te posłużyły jako materiał do analizy i oceny zachowań niewerbalnych tłumaczących, które dopełniły ocenę warstwy tekstowej przekładów.

W trakcie eksperymentu wykorzystałem dwa nagrania wystąpień dotyczących problemu niewerbalności w komunikacji międzyludzkiej. Wystąpienie w języku angielskim trwało 6 minut i 47 sekund, a liczba słów w nim użytych to 1091, natomiast wystąpienie w języku rosyjskim trwało 3 minuty i 19 sekund i użyto w nim 453 słów. Tak znacząca rozbieżność pomiędzy długością nagrań i liczbą słów w obu wystąpieniach wynikała z tego, że wystąpienie w języku angielskim w dużej mierze składało się z powtórzeń i wtrąceń. Poziom nasycenia informacjami w obu tekstach był mimo to porównywalny - został ustalony na podstawie indeksu czytelności, który w przypadku tekstu angielskiego wyniósł 77,5, a w przypadku tekstu rosyjskiego - 73. Co istotne, w trakcie nagrywania obu wystąpień obecna była publiczność, dlatego też prelegentki kilkakrotnie zwracały się do niej. Wszyscy uczestnicy eksperymentu zostali o tym poinformowani i poproszeni o nietłumaczenie odpowiedzi publiczności, gdyż były one niesłyszalne. 
Początkowo dążyłem do tego, aby zdania, których dokładność tłumaczenia podlegała ocenie, zostały równomiernie rozlokowane w czasie całego wystąpienia w celu zminimalizowania efektu domina. Okazało się jednak, że znaczące i wyraźne gesty obu prelegentek grupowały się w określonych miejscach, podczas gdy w pozostałych trudno było je wyodrębnić. Na tej podstawie można stwierdzić, że w przypadku obu prelegentek natura gestów była sekwencyjna, gdyż jeden gest potrafił towarzyszyć całemu zdaniu lub kilka gestów potrafiło wystąpić jeden po drugim. Mając to na uwadze, wybrałem do analizy i oceny zdania, którym towarzyszyły wyraziste gesty i które miały ewidentny związek z płaszczyzną tekstową wystąpienia. Jako że spośród czterech opisanych kategorii gestów prelegentki używały dwóch, a mianowicie ilustratorów i emblematów, to właśnie one zostały uwzględnione w eksperymencie.

Po przetranskrybowaniu nagrań źródłowych określiłem w ich ramach obszary zainteresowania, a więc zdania, które były skorelowane z dwiema wspomnianymi kategoriami gestów: ilustratorami lub emblematami. Następnie w każdym z przekładów odszukałem zdania będące ekwiwalentami wybranych obszarów zainteresowania z wystąpień źródłowych i je przetranskrybowałem. Dalej, po podzieleniu wszystkich zdań na jednostki syntagmatyczne, przeprowadziłem analizę odpowiedniości występującej pomiędzy tekstami źródłowymi i przekładami. W tekście angielskim wybrałem 12 zdań skorelowanych z ilustratorami i 5 zdań skorelowanych z emblematami, a w tekście rosyjskim -6 zdań skorelowanych z ilustratorami i 4 zdania skorelowane z emblematami. Gesty eksplicytnie powiązane ze znaczeniem słów prelegentek przypisałem do kategorii ilustratorów, a te, które mogłyby być zinterpretowane bez odwołania do słów, przypisałem do kategorii emblematów.

$\mathrm{W}$ trakcie zajęć z tłumaczenia ustnego, prowadzonych przez wykładowców ówczesnego Instytutu Filologii Angielskiej i Instytutu Filologii Rosyjskiej, wyznaczyłem po dwie sesje eksperymentalne z każdą z grup uczestników. Były to dla studentów pierwsze zajęcia $\mathrm{w}$ danym dniu, dzięki czemu można było wykluczyć wpływ ich zmęczenia na jakość przekładów. Każdą z grup poinformowałem o eksperymencie $\mathrm{z}$ tygodniowym wyprzedzeniem. Przed badaniem powiedziałem uczestnikom, że będą tłumaczyć wystąpienie prelegenta z nagrania i wskazałem jego temat. Uczestnicy celowo nie zostali poinformowani o problemie istotnym dla eksperymentu, aby nie wpłynąć na ich zachowanie i stosunek do zadania. Dodatkowo zostali poproszeni o wyrażenie zgody na bycie nagrywanymi i na wykorzystanie ich wizerunków w ewentualnych publikacjach.

Uczestnicy zostali przydzieleni albo do grupy audio, albo do grupy audio-wideo w wyniku losowania. Od strony technicznej eksperyment został przeprowadzony następująco - dwa telewizory podwieszone pod sufitem na środku sali zwrócone w stronę kabin tłumaczących pasmo audio zostały wyłączone, 
natomiast pozostałe dwa - włączone. Członkowie obu grup wchodzili do sali w porządku alfabetycznym i siadali po jednej ze stron sali zgodnie z przydzieloną im grupą. W przypadku grupy studentów filologii angielskiej miały miejsce dwie tury eksperymentalne - pierwsza przy udziale czterech osób (dwie z grupy audio, dwie z grupy audio-wideo), druga przy udziale trzech osób (jedna z grupy audio, dwie z grupy audio-wideo). Jeśli chodzi o grupę studentów filologii rosyjskiej, to $\mathrm{w}$ ich przypadku miały miejsce trzy tury eksperymentalne - dwie, w których tłumaczyła jedna osoba z każdej z grup, i jedna, ostatnia, w której tłumaczyła tylko jedna osoba $\mathrm{z}$ grupy audio-wideo. W przypadku thumaczenia z języka rosyjskiego na polski zdecydowałem o ograniczeniu liczby studentów biorących udział w turze $\mathrm{z}$ czterech do dwóch, by uniknąć kontrolowania czterech aparatów cyfrowych na raz. Było to spowodowane tym, że w grupie studentów filologii angielskiej właśnie $\mathrm{z}$ tego powodu nie udało się nagrać $1 / 3$ przekładu jednego z uczestników.

Na początku każdej z tur odtworzyłem kilka sekund nagrania, aby upewnić się, czy każdy z uczestników słyszy albo widzi i słyszy nagranie (odpowiednio do grupy). Następnie odtworzyłem nagranie od początku do końca. Gdy uczestnicy eksperymentu zakończyli thumaczenie, rozdałem im kwestionariusze, ponieważ chciałem zebrać informacje związane z ich odczuciami odnośnie do wykonanego zadania - zostało to zainspirowane eksperymentem Bühler (Bühler). Poprosiłem uczestników o udzielenie odpowiedzi wraz z uzasadnieniem na trzy pytania:

1. Czy thumaczenie sprawiło Panu/Pani jakiekolwiek trudności?

2. Czy uważa Pan/Pani, że możliwość widzenia prelegenta lub brak takiej możliwości ułatwiła/utrudniła Panu/Pani tłumaczenie?

3. Czy uważa Pan/Pani, że możliwość widzenia prelegenta lub brak takiej możliwości w jakikolwiek sposób wpłynęłaby na jakość Pana/Pani przekładu?

Uczestnicy eksperymentu otrzymali w kwestionariuszu wersję pytania nr 2 i 3 odpowiadającą ich grupie. W odpowiedzi na pytanie nr 2 uczestnicy mieli możliwość podzielenia się refleksjami na temat wykonanego zadania, a na pytanie nr 3 - przedstawienia swoich przypuszczeń. W ten sposób chciałem sprawdzić, czy uczestnicy badania odczuli wpływ widoczności/niewidoczności prelegentów na swoją psychikę i przekład, a także czy zadawali sobie sprawę z konsekwencji sytuacji, w której znaleźliby się, gdyby trafili do innej grupy.

Po przetranskrybowaniu tekstów źródłowych i ich przekładów podzieliłem wybrane zdania skorelowane z ilustratorami i emblematami na zdania składowe (syntagmy), aby ocenić dokładność przekładów każdego z uczestników eksperymentu. Celem analizy było ustalenie, czy podstawowe jednostki sensu zawarte w każdej z syntagm zostały odzwierciedlone w przekładach, czy nie. Oznacza to, 
że oceniłem jakość przekładów na poziomie części zdania, a nie słów. Przykładowy podział zdania prezentował się następująco:

/Cos, quite frankly /, how we talk to each other / and how we behave / are two very strongly interwoven things/.

Z powyższego przykładu wynika, że w ramach tego zdania wydzieliłem cztery syntagmy. W celu oceny dokładności przekładów zastosowałem uproszczoną wersję metody oceny odpowiedniości syntagmatycznej autorstwa Magdaleny Bartłomiejczyk (Bartłomiejczyk 188). Każda syntagma poprawnie zrekonstruowana w przekładzie otrzymała jeden punkt. Zero punktów przyznawane było syntagmom pominiętym, przetłumaczonym niepoprawnie pod względem językowym i w których znaczenie źródłowe zostało zmienione. Należy zwrócić uwagę, że w przekładach wystąpiły dwa typy błędów w obrębie ostatniej kategorii: po pierwsze dodanie negacji do poprawnie przethumaczonej syntagmy, po drugie zmiana wyjściowego związku zgody pomiędzy podmiotem i orzeczeniem w taki sposób, że zdanie stawało się niezrozumiałe. Kiedy wszystkie przekłady zostały ocenione, obliczyłem średnie wartości punktów dla każdej z grup, oddzielnie dla zdań skorelowanych z ilustratorami i emblematami. W analizie uwzględniłem nie tylko jakość przekładów, ale też gestykulację uczestników eksperymentu, ponieważ była ona widoczna na nagraniach.

Jeśli chodzi o thumaczenie $\mathrm{z}$ języka angielskiego na polski, to maksymalna liczba punktów, jaką uczestnicy eksperymentu mogli zdobyć, wyniosła 52 dla ilustratorów i 21 dla emblematów. W przypadku ilustratorów średnia ocen jakości przekładów dla całej grupy audio wyniosła 37,3 punktu (71\% maksymalnej liczby punktów), a w przypadku grupy audio-wideo - 29,25 punktu (56\%). W związku z tym grupa audio osiągnęła wyższy poziom dokładności przekładów względem tekstu źródłowego niż grupa audio-wideo. Jest to sprzeczne z postawioną hipotezą, jako że zgodnie z nią to grupa audio-wideo powinna była przetłumaczyć te zdania lepiej. W przypadku emblematów grupa audio uzyskała 12,66 punktu (60\%), a grupa audio-wideo - 16 punktów (76\%) i w ten sposób hipoteza została potwierdzona.

Tabela 1. Wyniki angielsko-polskiego thumaczenia symultanicznego dla zdań skorelowanych z ilustratorami i emblematami

\begin{tabular}{|l|c|c|c|c|}
\hline Uczestnik & \multicolumn{2}{|c|}{ Grupa audio } & \multicolumn{2}{c|}{ Grupa audio-wideo } \\
\hline & $\begin{array}{c}\text { Ilustratory } \\
\text { (maks. 52) }\end{array}$ & $\begin{array}{c}\text { Emblematy } \\
\text { (maks. 21) }\end{array}$ & $\begin{array}{c}\text { Ilustratory } \\
\text { (maks. 52) }\end{array}$ & $\begin{array}{c}\text { Emblematy } \\
\text { (maks. 21) }\end{array}$ \\
\hline U1 & 34 & 12 & - & - \\
\hline U2 & 42 & 16 & - & - \\
\hline
\end{tabular}




\begin{tabular}{|l|c|c|c|c|}
\hline U3 & 36 & 10 & - & - \\
\hline U4 & - & - & 22 & 18 \\
\hline U5 & - & - & 30 & 15 \\
\hline U6 & - & - & 32 & 16 \\
\hline U7 & - & - & 33 & 15 \\
\hline & Średnia: 37,3 & Średnia: $\mathbf{1 2 , 6 6}$ & Średnia: 29,25 & Średnia: 16 \\
\hline
\end{tabular}

Jeśli chodzi o uczestników z grupy audio-wideo, w odpowiedziach do pytań z kwestionariuszy kilkoro z nich zwróciło uwagę, że niewidzenie prelegentki zmusiłoby ich do zaangażowania dodatkowych zasobów kognitywnych w celu wyobrażenia sobie, o czym prelegentka mówiła. Ich zdaniem, mogło to prowadzić do szybszego zmęczenia i utraty precyzji tłumaczenia. Co więcej, niektórzy twierdzili, że w momentach, kiedy mieli problem ze zrozumieniem słów prelegentki - ze względu na słabą jakość dźwięku lub odgłosy w tle - wykorzystywali kinezykę jako pomoc w zrozumieniu komunikatu. Była ona dla nich źródłem dodatkowych informacji, co jest całkowicie zgodne z przywołanym na początku artykułu założeniem Seebera o korzystnym wpływie integracji audiowizualnej na proces komunikacji (Seeber 2017: 462). W taki sposób w sytuacjach, kiedy tłumaczący nie rozumieli słów, odwoływali się do gestów prelegentki, traktując je jako kanał przekazu informacji, równoważny wobec słów. Na tej podstawie można wywnioskować, że gesty były narzędziem rozszerzającym przekaz, co implikuje lepsze rozumienie i tłumaczenie wypowiedzi pod warunkiem utrzymywania kontaktu wzrokowego z prelegentami.

Odnośnie do uczestników z grupy audio, należy przytoczyć opinię jednej osoby, iż dostęp do pasma wideo pozwoliłby nie tylko na zachowanie spójności przekładu, lecz również na efektywniejsze przekazanie wydźwięku wypowiedzi. Ponadto jedna z tłumaczących zauważyła, że gdyby widziała prelegenta, to wpłynęłoby to lepiej na jej samopoczucie, gdyż nie byłaby tak odosobniona i niepewna. Co ważne, tylko jedna uczestniczka zwróciła uwagę, że niemożność obserwowania całej sytuacji komunikacyjnej w nagraniu sprawiła, iż nie była w stanie zrozumieć i przewidzieć takich momentów, w których dochodziło do interakcji pomiędzy prelegentką a publicznością.

To skłania do wniosku, że także regulatory mogą mieć istotny wpływ na jakość przekładu symultanicznego - dostęp wizualny do nich pozwala tłumaczowi na przygotowanie się do zmiany osoby wypowiadającej się i zrozumienie atmosfery zachodzących interakcji. Dotyczyło to np. sytuacji, kiedy prelegentka kiwała głową $\mathrm{w}$ odpowiedzi na podniesioną rękę jednej z osób spośród publiczności, pozwalając jej na zabranie głosu. Tłumaczący z grupy audio-wideo widzieli te interakcje i byli przygotowani na wtrącenia ze strony innych osób, podczas gdy 
grupa audio była tym zaskoczona. Niemniej jednak jedna z uczestniczek uznała, że dostęp do pasma wideo (widoczność tablicy, publiczności) ją rozpraszał właśnie ze względu na wielopłaszczyznowość.

Jak widać w tabeli 1, członkowie grupy audio przetłumaczyli zdania zawierające ilustratory o $15 \%$ dokładniej niż członkowie grupy audio-wideo. Może to sugerować, że w danym wypadku ilustratory nie niosły dodatkowego znaczenia z punktu widzenia tłumaczących. W istocie to właśnie dla osoby mówiącej ilustratory stają się najbardziej użyteczne, gdyż stanowią środek ekspresji - są powiązane ze stosunkiem nadawcy do komunikatu. W przeciwieństwie do redundantności emblematów, ilustratory są komplementarne wobec mowy. Należy w tym miejscu podkreślić, iż grupa audio tłumaczyła dokładniej niż grupa audio-wideo, lecz ta dokładność sprowadzała się do liczby syntagm i słów. Jej członkowie nie mieli możliwości zweryfikowania poprawności rozumienia słów prelegenta, co zmusiło ich do odtworzenia w przekładach tylko warstwy słownej wystąpienia. Potwierdza to fakt, że członkowie grupy audio-wideo thumaczyli bardziej rozwlekle i opisowo, tracąc cenne sekundy i przeciążając zasoby kognitywne. Niektórzy z nich parafrazowali kilka razy z rzędu tę samą syntagmę źródłową, co można zinterpretować jako przesadne skupienie na gestach w celu zwiększenia precyzji thumaczenia. Mówiąc inaczej, thumaczący opisywali to, co widzieli na ekranie, zamiast podążać za prelegentką kontynuującą swój wywód. To powodowało pomijanie kolejnych fraz i utratę punktów przyznawanych za dokładność tłumaczenia. Na podstawie wyników eksperymentu można sądzić, iż uwaga członków grupy audio-wideo została odwrócona przez ilustratory, gdyż w ich opinii były one źródłem większej ilości informacji, niż miało to miejsce w rzeczywistości. Wiązało się to z tym, że ilustratory uzupełniają warstwę słowną. Co ciekawe, w kwestionariuszach wszyscy thumaczący $z$ tej grupy zgodnie twierdzili, że płaszczyzna niewerbalna ułatwiła im rozumienie i thumaczenie oryginalnej wypowiedzi.

W przeciwieństwie do ilustratorów, emblematy sprawiły, że grupa audio-wideo przetłumaczyła zdania skorelowane z nimi o 16\% lepiej od grupy audio. Ich natura, jak podkreśliłem przy opisywaniu kategorii gestów, sprowadza się do znaczenia niezależnego - stanowią one równoważniki całych fraz. Wyniki te potwierdzają obserwację, zgodnie z którą redundantne wobec mowy sygnały niewerbalne ułatwiają jej zrozumienie. Emblematy są gestami, za pomocą których osoba mówiąca może powtórzyć znaczenie przekazywane za pomocą słów. Wydaje się więc, że tłumacze wykorzystują to, porównując słowa z gestami i poszukując powiązań pomiędzy nimi. W przypadku eksperymentu tłumaczący stosowali tę zasadę nie tylko do zdań, z których zrozumieniem nie mieli problemu, lecz też do tych, których znaczenie nie było jasne. Dzięki uwzględnianiu emblematów tłumaczący albo potwierdzali, albo odrzucali swoje pierwotne interpretacje słów prelegentki. Istotne jest, że prelegentka używała emblematów, przede wszystkim 
mówiąc o konkretnych gestach. Dla przykładu, kiedy poruszała kwestię osób mających w zwyczaju dotykać swoich współrozmówców, jednocześnie wizualizowała to poprzez położenie ręki na ramieniu. Uczestniczka $6 \mathrm{z}$ grupy audio-wideo przetłumaczyła ten fragment wypowiedzi jako „osoby, które są blisko”, a potem jako „osoby, które odpychają naszą rękę”. Dopiero po sześciu sekundach przetwarzania komunikatu źródłowego poprawiła się, wypowiadając słowa „osoby, które klepią cię po ramieniu".

Pozwala to zauważyć, że członkowie grupy audio tłumaczyli wypowiedź prelegentki słowo po słowie, a członkowie grupy audio-wideo - opisowo. Ci pierwsi pominęli dwie syntagmy, ci drudzy aż osiem. Na podstawie tych liczb można uznać, że z jednej strony członkowie grupy audio słuchali uważniej słów prelegentki i starali się dokładniej oddawać strukturę wypowiedzi źródłowej w swoich przekładach, lecz mimo to nie udało im się lepiej przetłumaczyć zdań zawierających emblematy. W tym przypadku zadanie było łatwiejsze dla grupy audio-wideo, jako że gesty służyły prelegentce do wizualizacji tego, o czym mówiła. Tłumaczący mieli możliwość ciągłego konfrontowania płaszczyzny werbalnej i niewerbalnej. $Z$ drugiej strony strategia thumaczenia posłownego zastosowana przez grupę audio okazała się efektywna w przypadku ilustratorów, gdyż pojawiały się one wraz ze zdaniami opisującymi teorię komunikacji niewerbalnej. Za ich pośrednictwem prelegentka odzwierciedlała tempo wypowiedzi, podobieństwa i różnice pomiędzy poruszanymi kwestiami, jak również stosunek emocjonalny do tematu.

Jeśli chodzi o thumaczenie z języka rosyjskiego na polski, to w tym przypadku maksymalna liczba punktów, jaką uczestnicy eksperymentu mogli uzyskać, wyniosła 18 dla zdań skorelowanych z ilustratorami i 19 dla zdań skorelowanych z emblematami. W przypadku ilustratorów średnia ocen jakości przekładów dla całej grupy audio wyniosła 6,5 punktu (36\% maksymalnej liczby punktów), a w przypadku grupy audio-wideo - 11,6 punktu (64\%). W przypadku emblematów grupa audio uzyskała 5 punktów (26\%), a grupa audio-wideo - 13 punktów (68\%). Hipoteza została więc potwierdzona zarówno w odniesieniu do zdań skorelowanych z ilustratorami, jak i z emblematami.

Tabela 2. Wyniki rosyjsko-polskiego tłumaczenia symultanicznego dla zdań skorelowanych $\mathrm{z}$ ilustratorami i emblematami

\begin{tabular}{|l|c|c|c|c|}
\hline Uczestnik & \multicolumn{2}{|c|}{ Grupa audio } & \multicolumn{2}{c|}{ Grupa audio-wideo } \\
\hline & $\begin{array}{c}\text { Ilustratory } \\
\text { (maks. 18) }\end{array}$ & $\begin{array}{c}\text { Emblematy } \\
\text { (maks. 19) }\end{array}$ & $\begin{array}{c}\text { Ilustratory } \\
\text { (maks. 18) }\end{array}$ & $\begin{array}{c}\text { Emblematy } \\
\text { (maks. 19) }\end{array}$ \\
\hline U1 & 10 & 3 & - & - \\
\hline U2 & 3 & 7 & - & - \\
\hline U3 & - & - & 10 & 15 \\
\hline
\end{tabular}




\begin{tabular}{|l|c|c|c|c|}
\hline U4 & - & - & 15 & 13 \\
\hline U5 & - & - & 10 & 11 \\
\hline & Średnia: 6,5 & Średnia: 5 & Średnia: 11,6 & Średnia: 13 \\
\hline
\end{tabular}

W wypadku pierwszej kategorii używanych gestów grupa audio-wideo była lepsza od grupy audio o $28 \%$, a w wypadku drugiej kategorii gestów - o 42\%. Wyniki sugerują, że grupa rosyjsko-polska - mając mniej doświadczenia od grupy angielsko-polskiej - była w stanie lepiej wykorzystać dostęp do gestosfery prelegentki. Mogło to wynikać z faktu, że rosyjski tekst był krótszy, tempo wypowiedzi wolniejsze, a prelegentka używała gestów w sposób bardziej wyrazisty. Dodatkowo sami uczestnicy spoglądali na ekran dłużej, co mogło wpłynąć na zniwelowanie problemów w odbiorze komunikatu. To zostało odzwierciedlone w ich przekładach, dlatego że grupa audio-wideo pominęła tylko cztery syntagmy, a grupa audio - dziewięć. Można wnioskować, że możliwość patrzenia na prelegentkę przełożyła się na większą dokładność i pewność w tłumaczeniu u członków grupy audio-wideo.

Kolejnym istotnym aspektem eksperymentu była komunikacja niewerbalna thumaczących, gdyż taka analiza nie może skupiać się wyłącznie na niewerbalności prelegenta. Kinezyka i prozodia tłumaczących w grupie angielsko-polskiej przez większość czasu pozostawała względnie monotonna. Najbardziej jawnym odzwierciedleniem stanu psychicznego uczestników eksperymentu było ich spojrzenie, gdyż grupa audio-wideo często przenosiła wzrok poza ekran w trakcie przetwarzania komunikatu. $\mathrm{Z}$ kolei grupa audio skupiała wzrok w jednym miejscu przez większość czasu. Podobieństwo w kwestii gestów między obiema grupami sprowadzało się do tego, że ich członkowie mieli tendencję do machania rękoma w trakcie tłumaczenia (używania batut), tak jakby starali się przyspieszyć tempo swojego tłumaczenia i zmobilizować się do większej skuteczności. Oprócz tego, ze względu na świadomość, że byli nagrywani, tłumaczący używali adaptatorów i spoglądali w obiektyw - były to niewątpliwie objawy efektu obserwatora.

Szczególnym obiektem mojego zainteresowania było to, w jakim stopniu tłumaczący odzwierciedlali zachowania niewerbalne prelegentek. W przypadku thumaczących z grupy angielsko-polskiej wydarzyło się to dwukrotnie. Po pierwsze, uczestniczka 7 odwzorowała pochylenie się prelegentki nad biurkiem w trakcie wypowiadania słów ,jeśli osoba pochyla się w twoją stronę w ten sposób” poprzez delikatne wychylenie swojego torsu. Po drugie, uczestniczka 6 odzwierciedliła skrzyżowanie ramion prelegentki poprzez wypchnięcie ramion przed siebie. Rzucało się w oczy także to, że uczestnik 3 z grupy audio gestykulował, modulował swój głos i używał mimiki o wiele bardziej żywiołowo niż prelegentka. Mogło to wynikać albo z działania efektu obserwatora, albo z tego, że nie widział 
prelegentki. Gdyby druga sytuacja faktycznie miała miejsce, to należałoby to interpretować jako instynktowne dążenie do kompensacji braku dostępu do strony wizualnej nagrania.

Zachowania niewerbalne tłumaczących $\mathrm{z}$ grupy rosyjsko-polskiej były porównywalne do tych z grupy angielsko-polskiej, ponieważ wykorzystywali oni gesty w celu zmotywowania siebie do uzyskania większej efektywności tłumaczenia. Można było również zauważyć oznaki dezorientacji po stronie członków grupy audio, co przede wszystkim dotyczyło tych fragmentów wystąpienia prelegentki, których nie rozumieli. Zwrócili na to uwagę w odpowiedziach do pytań z kwestionariuszy - wszyscy opisali towarzyszące im uczucie odseparowania od thumaczonej sytuacji komunikacyjnej. W przeciwieństwie do thumaczących z angielskiego na polski, w tej grupie miała miejsce sytuacja, w której członkini grupy audio-wideo gestykulowała równolegle z prelegentką. Uczestniczka 3 czuła naturalną potrzebę wyrażenia sensu swoich słów za pomocą sygnałów niewerbalnych, nie odczuwając presji wynikającej z tego, że jest nagrywana. Trzeba zaznaczyć, że w większości przypadków używała innych gestów niż prelegentka, ale w tych samych momentach wystąpienia. Przede wszystkim dotyczyło to jego drugiej części, co może być powiązane ze spadkiem początkowo wysokiego poziomu stresu. W taki sposób uczestniczka przetłumaczyła nie tylko słowa prelegentki, lecz również jej gesty, jednak dokonała tego za pośrednictwem gestów innych niż w wystąpieniu źródłowym.

Jeśli chodzi o potencjalne zastrzeżenia, które mogą pojawić się w odniesieniu do przeprowadzonego eksperymentu, głównym z nich może być temat wystąpień prelegentów, czyli komunikacja niewerbalna. Mówienie o niej bez wątpienia wymusza wykorzystywanie znaków niewerbalnych w sposób sztuczny jako przykładów, co w przypadku innej tematyki wystąpień mogłoby nie mieć miejsca. Przełożyło się to chociażby na moment, kiedy amerykańska prelegentka mówiła o haptyczności i wykonywała rękami ruchy przypominające dotykanie niewidzialnej osoby. Na dodatek w obu wystąpieniach było kilka sytuacji, w których prelegentki używały wyrażeń deiktycznych w celu wskazania na wykonywany przez nie gest. Dla grup audio-wideo ten gest był w zasięgu wzroku, więc nie dość, że wiedziały, co osoby mówiące mają na myśli, to mogły zastąpić wyrażenie deiktyczne opisem użytego sygnału niewerbalnego. Osoby z grup audio poradziły sobie jednak z tym problemem, gdyż dosłownie przetłumaczyły użyte wyrażenie deiktyczne, zakładając, że hipotetyczni odbiorcy ich tłumaczenia widzą to, do czego ono odsyła.

Trzy kluczowe ograniczenia eksperymentu były następujące: brak profesjonalnego doświadczenia uczestników, tłumaczenie wypowiedzi z nagrania, a nie na żywo oraz liczba uczestników. Po pierwsze, jako że uczestnicy eksperymentu dopiero kształcili się w obszarze thumaczenia ustnego, nie mieli jeszcze wypracowanych i zautomatyzowanych strategii radzenia sobie z problemami thumacze- 
niowymi, w tym z identyfikowaniem informacji zbędnych. Oprócz tego mogli być bardziej podatni na stres i nieprzyzwyczajeni do wykonywania zadań thumaczeniowych pod presją. Po drugie, ze względu na fakt, że uczestnicy eksperymentu thumaczyli wystąpienie z nagrania, można stwierdzić, że takie zadanie zbliżone było do tłumaczenia zdalnego. Istnieje prawdopodobieństwo, że wystąpienia prelegentek byłyby postrzegane przez tłumaczących inaczej, gdyby i jedni, i drudzy znajdowali się w tym samym pomieszczeniu (Moser-Mercer; Mouzorakis). Zależało mi jednak na tym, aby wszyscy uczestnicy eksperymentu tłumaczyli dokładnie tę samą wersję wystąpienia, gdyż liczba kabin w sali nie pozwalała na jednoczesne umieszczenie w nich wszystkich tłumaczących. Po trzecie, niewielka liczba uczestników eksperymentu nie pozwala na sformułowanie uogólnienia odnośnie do tego, że pozytywny wpływ dostępu tłumacza do płaszczyzny komunikacji niewerbalnej prelegenta na jakość przekładu symultanicznego jest uniwersalny. Jest to raczej obserwacja, która powinna być poddana operacjonalizacji i weryfikacji na większej grupie tłumaczy (wartościowe byłoby porównanie wyników tłumaczy amatorów i zawodowych tłumaczy).

Podsumowując niniejszy artykuł, pragnę zauważyć, że teza o integracji audiowizualnej w procesie komunikacji, która została postawiona przez Seebera (2017), ma przełożenie na realia tłumaczeniowe. Z eksperymentu wynika, iż pierwsza hipoteza o pozytywnym wpływie sygnałów niewerbalnych na jakość przekładu symultanicznego została potwierdzona $\mathrm{w} 3 / 4$ (za wyjątkiem grupy angielsko-polskiej w przypadku zdań skorelowanych z ilustratorami). Druga hipoteza, w myśl której grupom audio-wideo powinno się tłumaczyć łatwiej pod względem psychologicznym, została potwierdzona na podstawie subiektywnych odczuć uczestników eksperymentu, opisanych przez nich w kwestionariuszach. Z kolei trzecia hipoteza o odzwierciedlaniu komunikacji niewerbalnej prelegenta przez tych tłumaczy, którzy go widzą, została potwierdzona częściowo - troje uczestników powtarzało niektóre gesty prelegentek. Na podstawie przekładów i zachowania uczestników eksperymentu można uznać, że komunikacja niewerbalna rzeczywiście może być istotna w procesie tłumaczenia symultanicznego. Potwierdzenie tej obserwacji na szerszą skalę wymaga zastosowania spójnej metodologii badawczej i przeprowadzenia obszerniejszej dyskusji teoretycznej. Dzięki temu możliwe będzie ułatwienie pracy tłumaczom symultanicznym i dopełnienie sylabusów stanowiących podstawę programową kursów kształcących przyszłych thumaczy ustnych.

\section{Bibliografia}

Anderson, Linda. „Simultaneous interpretation: Contextual and translation aspects”. Bridging the gap: Empirical research in simultaneous interpretation. Red. Sylvie Lambert, Barbara Moser-Mercer. Amsterdam, John Benjamins Publishing Company, 1994, s. 101-120. 
Balzani, Maurizio. „Le contact visuel en interpretation simultanée: resultats d'une expérience (Français-Italien)". Aspects of applied and experimental research on conference interpretation. Red. Laura Gran, Christopher Taylor. Udine, Campanotte Editore, 1990, s. 93-100.

Bartłomiejczyk, Magdalena. „Effects of short intensive practice on interpreter trainees’ performance". Why translation studies matters. Red. Daniel Gile, Gyde Hansen, Nile K. Pokorn. Amsterdam, John Benjamins Publishing Company, 2010, s. 183-194.

Bühler, Hildegund. „Conference interpreting: A multichannel communication phenomenon”. Meta: Translators' Journal, 30 (1), 1985, s. 49-54.

Burgoon, Judee K., Aaron Bacue. „Nonverbal communication skills”. The handbook of communication and social interaction skills. Red. John O. Greene, Brant R. Burleson. Mahwah, Lawrence Erlbaum Associates Publishers, 2003, s. 179-219.

Ekman, Paul. „Emotional and conversational nonverbal signals”. Language, knowledge, and representation. Red. Jesús M. Larrazabal, Luis A. Perez Miranda. Dordrecht, Springer Science+Business Media, 2004, s. 39-50.

Ekman, Paul, Wallace V. Friesen. „The repertoire of nonverbal behavior: Categories, origins, usage, and coding". Semiotica, 1 (1), 1969, s. 49-98.

Fujishin, Randy. „Creating effective groups: The art of small group communication”. Plymouth, Rowman \& Littlefield Publishers, 2007.

Galvão, Elena Z. „Speech and gesture in the booth - A descriptive approach to multimodality in simultaneous interpreting". Translation and the (Trans)formation of Identities. Selected Papers of the CETRA Research Seminar in Translation Studies 2008. Red. Dries De Crom. 2009. Web. 14.11.2020. http://www.arts.kuleuven.be/cetra/papers/files/galvao.pdf.

Grabowski, Joachim. „The writing superiority effect in the verbal recall of knowledge: Sources and determinants". Writing and cognition. Red. Mark Torrance, Luuk van Waes, David Galbraith. Bingley, Brill, 2007, s. 163-179.

Jesse Alexandra et al. „The processing of information from multiple sources in simultaneous interpreting”. Interpreting, 5 (2), 2000/2001, s. 95-115.

Moser-Mercer, Barbara. „Remote interpreting: Issues of multi-sensory integration in a multilingual task". Meta: Translators' Journal, 50 (2), 2005, s. 727-738.

Mouzorakis, Panayotis. „That feeling of being there: Vision and presence in remote interpreting”. Web. 14.11.2020. https://www.academia.edu/25852376/That_feeling_of_being_there_Vision_ and_presence_in_remote_interpreting.

Osika, Grażyna. „Komunikacja niewerbalna”. Zeszyty Naukowe Politechniki Śląskiej. Seria: Organizacja i Zarzadzanie, 43, 2008, s. 111-128.

Rachut, Konrad. „Komunikacja niewerbalna a thumaczenie symultaniczne: Aspekt teoretyczny”. Acta Neophilologica, 21 (2), 2019, s. 65-75.

Rennert, Sylvi. „Visual input in simultaneous interpreting”. Meta: Translators' Journal, 53 (1), 2008, s. 204-217.

Seeber, Kilian G. „Multimodal input in simultaneous interpreting: An eye-tracking experiment”. Translation Studies: Old and new types of translation in theory and practice. Proceedings of the 1st International Conference TRANSLATA. Translation \& interpreting research: Yesterday? Today? Tomorrow. Red. Lew Zybatow, Alena Petrova, Michael Ustaszewski. Frankfurt am Main, Peter Lang, 2012. Web. 14.11.2020. https://archive-ouverte.unige.ch/unige:97482.

Seeber, Kilian G. „Multimodal processing in simultaneous interpreting”. The Handbook of Translation and Cognition. Red. John W. Schwieter, Aline Ferreira. Hoboken, John Wiley \& Sons, Inc., 2017, s. 461-475.

Sternberg, Robert. Cognitive psychology. Belmont, Wadsworth Publishing, 2011.

Verderber, Rudolph, Kathleen Verderber, Dean Sellnow. COMM. Wadsworth, Cengage Learning, 2009. 